Global Conferences Series:

Social Sciences, Education and Humanities (GCSSSEH), Volume 2, 2019

The $2^{\text {nd }}$ International Conference on Sustainable Development \& Multi-Ethnic Society

DOI: https://doi.org/10.32698/GCS.01105

\title{
Multiculturalism of Education System in Shaping National Identity of Malaysia's Students
}

\author{
Phang Chi Lick ${ }^{1}$, Mohd Mahzan Awang ${ }^{2}$, Abdul Razaq Ahmad ${ }^{3}$ \& Anuar Ahmad ${ }^{4}$ \\ ${ }^{1234}$ Faculty of Education UKM, MALAYSIA \\ E-mail: Rainphang@gmail.com
}

\begin{abstract}
This study will look at the educational system practiced by our country in shaping an ideal society. This paper will address issues related to national identity, multiculturalism and debate in the single and multi-stream education system. In addition, this concept paper aims to review and identify the extent to which the multiculturalism of the educational system which practiced by our country in an effort to shape the national identity of students as they build an ideal society. The relationship between patriotism and national identity among students in Malaysia will be commented on based on the facts obtained. Nursi's Unity model was chosen to serve as a special mechanism for fostering unity among Malaysian students under the auspices of the multicultural education system. This model will be covered in this concept paper.
\end{abstract}

Keywords: Multiculturalism, education system, national identity, Nursi's Unity Model

\section{Introduction}

Our country is arguably unique in its educational system compared to other countries. This is because Malaysia allows for the presence of ethnic-based education, the vernacular school system. However, there are also Chinese private schools that are not recognized by the government as they are alleged to have used the learning system from Taiwan instead of Malaysia. The existence of the vernacular education system has often been a political polemic for some politicians to cause confusion and support during the election season.

The policy of the government in the national education system is to encourage parents to send their children to the National School so that the process of socialization within students of various races can be established. Nonetheless, the racially based schooling system is still maintained due to the historical background and the urge of non-Malays who do not want their language and culture removed (Abd Aziz A'zmi et al., 2017). Besides that, the author argues that a vernacular education system is a form of compromise to the people of Malaysia in order to achieve a stable national unity. The diversity of the country's education system leads to three faces, namely positive, negative and desirable faces in policy implementation (Shamsul Amri \& Anis Yusal 2014).

To this day, debates between single-stream and multi-stream schools still prevail among scholars, politicians and community members. Some said that the multicultural education system causes students to lose their national identity because they rarely mix with other ethnic groups, 
especially the Malays. Some even argued that diversity is a symbol of their national identity, regardless of the language, their hearts are still fond to their homeland.

\section{The Debate Between Single-Stream and Multi- Stream Education System in Shaping Unity of Society}

Frequently, there is a debate between the two sides as to whether the single-stream or multi-stream education system is the best way to unite the people of Malaysia. This has led to disputes that still exist today. In the Malaysian context, Malaysia uses a multi-stream system in its education system. Parents have the right to choose whichever stream of education as long as they can and that's their right.

According to Rejab F.I. (2015), a single-stream school is capable of shaping the personality of the people while preserving the harmony and well-being of the nation. This is because the one-language schools use only one language as the medium of instruction, which is the Malay language. The author also uses examples of Indonesian people of various races and ethnicity to overcome racial issues through the use of the Indonesia language.

Meanwhile, Prof Dato' Dr. Teo Kok Seong of the Institute for Ethnic Studies (KITA) said in the 23rd edition of the Persada Speech forum titled "Single-stream Schools: Needs and Possibilities", single-stream schools could create unity among students without compromising their students' original culture (Saiful Bahri Kamaruddin, 2015). When schools are integrated into one stream, Malay language will become a staple while Chinese and Tamil language will also be learned instead to bring along religious subjects in the school. Malaysia has 7 types of schools, including national schools, vernacular schools, religious schools, private schools, Chinese private schools, international schools and homeschooling.

However, there are also voices that oppose the single-stream education system. Among them is The Malaysian People's Movement Party (GERAKAN) President Datuk Dr. Dominic Lau Hoe Chai said that those who want a single-stream school or want to implement assimilation policies are those who do not understand the history of the country (Sajida Asarulah Khan, 2019). He also cited the examples of Thailand, Cambodia, Singapore and Indonesia that have gradually created more streams in their country's education system.

Zairil Khir Johari (2015) feels that the issue of separation in unity has nothing to do with vernacular or nonvernacular schools alone. It is actually related to the moral values and narratives embedded in the syllabus of our education system that the policymakers should question. He added that the idea that a multiracial education system prevented unity was a perverted idea.

\section{Patriotism and National Identity}

Patriotism and national identity are intertwined entities in which we look at how one interprets his or her identity as a Malaysian. National identity is an abstract and complex element as individuals' interpretations of it vary. Patriotism is the spirit of love for the country. However, we cannot deny that it is the essence of maintaining harmony among Malaysian society. Students' interpretations of national identities vary, depending on the environment in which they grew up and the educational system they are in. It is not uncommon for an ethnic group to maintain their identity before speaking up of national identity. Each ethnic group retains its own ethnic identity, especially in terms of descendants, language, religion, culture and customs.

The concept of national identity is quite broad. Thus, the concept has various interpretations and definitions. National identity is a collective sentiment in which a society has a certain set of beliefs and they share many of the same characteristics (Mohd Mahadee Ismail et al., 2016). In the meantime, the author also quotes the words of some scholars in his article to express the meaning of national identity. Among them is Fakri (2012) whose mentioned national identity is determined based on the spirit of belonging to a country with its own history, values and traditions. Smith (1991) argues that national identity should be viewed in terms of the extent to which people living within a political boundary define themselves based on a shared sense of belonging.

In the context of national identity among students in Malaysia, they are judged based on their sense of identity and nationalism. Besides, they are also seen in the ability to interact and collaborate with people of different cultures, values of life and even religions. Although a student is studying at the National Secondary School with students of various races and cultures, he is not necessarily able or willing to associate with other peers of different races and cultures. Whereas a person who attends Chinese Private School and is less involved with friends of different races and religions do not necessarily cannot cooperate with them.

However, prior to the question of students' national identity, there was a study explaining that there was some confusion among the Malays and that led to the confusion of national identity by Malaysian students today. According to Siti Rahimah Mustaffa et al (2014), there is a phenomenon of mixing of languages in the Malay language in which Malay is often mixed with English and this has become widespread 
in Malay society today. For respondents, this is common because English is widely used in various sectors and has a concrete meaning.

According to Sitti Hasnah Bandu (2015), patriotism is the passion of love towards one's birthplace. The interests of the country are placed above the self. Among the characteristics of patriotic people are those who have love and compassion for their homeland, proud of their homeland, ready to defend the country from internal and external threats and willingness to defend the country when humiliated.

So, the question is, what is the true national identity of Malaysian students in the multicultural education system? What characteristics do they have that are new to being classified as patriotic? Are those who fail the Malay language test are unpatriotic? These are some of the issues raised in this concept paper.

\section{Nursi's Unity Model}

When it comes to unity, we need a mechanism and agent to form a unity so that it is "tied" and not easily fragmented in order to support a multiracial education system. So, the Nursi's Unity Model was chosen because its concept was viewed in accordance with the context of Malaysia as a country of multiculturalism. The Nursi's Unity Model was founded by Badiuzzaman Said Nursi (1877-1960). He is a man that had conceptual thinking related to the identity of Muslims (Mohammad Zaidin Mohammad, 2018). Besides, he is also described as a scholar that had the high capability and skilled in traditional and modern knowledge (Muddasir Ahmad Dass, 2018).

Nursi's Unity Model emphasizes the following matters. Firstly, Wasatiyaah. Wasaytiaah is the key principle in this model and it means simplicity (Mohammad, M.Z., 2014). This principle is also supported by the concept of dialogue and the application of moral values to strengthen that main principle. When the principle of simplicity is applied, positive elements can be identified and this can reduce conflict and thus create a harmonious atmosphere. For example, a teacher cannot be so obsessed with his own beliefs that he cannot accept things that are contrary to his beliefs.

Secondly, dialogue. Dialogue is a good platform for interaction and it is a priority for a society of high civilization. In other words, it is a first-class mindset. Nursi's Unity Model defies all violence and extremism in daily life. Thirdly, strengthen the use of moral values. The model calls for people to strive in order to build unity by doing good and forbidding evil. In addition, this is one of the process of appreciating the good practice. In this aspect, initiatives can be taken within the school itself by facilitating cross-cultural dialogue between teachers and students. They can share with each other on how they live, eat, or about prohibit and this will increase understanding between the two sides.

According to Mohammad Zaidin Mohammad et al (2018), Nursi's thinking in building unity is to nurture universal values by accepting what is good and removing what is not wanted. In the context of the Malaysian education system, policymakers can make universal values a catalyst for the building of inter-school relationships. Cross-cultural programmes should be held consistently from the small community to the national level so that students from all streams have the opportunity to interact and get to know others' cultures.

\section{Conclusion}

As conclusion, the multiculturalism that is formed in our country today is not what anyone wishes to. This is the effect that colonialists left behind previously due to their greed and selfishness. However, our generation today can only move forward rather than keep looking back as history has happened. We need to find a solution to the problems as said in the Nursi's Unity Model, which is to have dialogue in order to make the spirit of wasatiyyah successful. Political leaders should also be role models in this part. If the political culture is still practicing racial and religious politics, we will remain static in moving towards first-class society.

The way a person's national identity is created should not be an issue as the education system that has been used so far has given Malaysian students the opportunity to show diversity. The important thing is that the people who hold a blue identity card status are still loyal to their country and not destroying national sovereignty. Every choice or system that have been chosen by the figures of independence in the past must have true meaning behind it. The present or future generations must work together to continuing their aspirations and constantly improving for better results.

Therefore, the debate between the implementation of a single or multi-stream in the education system towards unity is not a major issue to be looked at but the intention of every individual to see the future of the country. The essential elements of Nursi's must be accepted, expanded and implemented within the context of the education system to form a united society.

\section{References}

[1] Abd Aziz A'zmi, Farrah Wahida Mustafar, Aimi Kharunnisa, A.K. \& Nurliana Suhaimi. 2017. Realiti kepelbagaian kaum ke arah perpaduan nasional pasca merdeka. Jurnal Sains Sosial. 2: 1-24.

[2] Mohamad Zaidin Mohamad, Kamarul Shukri Mat Teh, Sofyuddin Yusof, Ahmad Fauzi Hassan, Ahmad Zahid Salleh, Ahmad Bukhori Ghazali. 2018. Building a 
personality by installing noble values: Implementing Nursi's thoughts in a Malaysia context. International Journal of Academic Research in Business and Social Sciences. 11: 437-444.

[3] Mohammad, M.Z., Kamaruzaman Yusoff, Ab. Aziz Sulaiman, Daud Ismail, Lazim Omar, Muhammad Zaid Ismail, Wan Abdullah, W.A., Azhar Yaacob, Mustafa Che Omar \& Mahadi Abu Bakar. 2014. Nursi's Unity Model and its importance in the context of racial unity in Malaysia. Mediterranean Journal of Social Sciences. 5(29): 87-92.

[4] Mohd Mahadee Ismail, Lee, Y.F., Ku Hasnita, K.S., Zatul, H.A., Azlina Abdullah \& Siaw Bing. 2016. Tafsiran harian identiti nasional: Pandangan akar umbi. Research Journal of Social Sciences. 9(3): 20-27.

[5] Muddasir Ahmad Dass. 2018. Revitalizing the intergrated knowledge: Said Nursi's educational model. Islamic Insight. 1(2): 79-92.

[6] Rejab, F.I. 2015. Sekolah satu aliran bentuk peribadi bangsa. Utusan Malaysia, 16 Okt: 18

[7] Saiful Bahri Kamaruddin. 2015. Wujudkan sekolah satu aliran jika semua kaum dirujuk dahulu - Bicara persada. http://www.ukm.my/news/Latest_News/wujudkansekolah-satu-aliran-jika-semua-kaum-dirujuk-dahulubicara-persada/

[8] Sajida Asarulah Khan. 2019. Sekolah satu aliran langkah kebelakang - Dominic. Utusan Malaysia, 7 Sept: 15

[9] Shamsul Amri Baharudin \& Anis Yusal Yusoff. 2014. Perpaduan, Kesepaduan, Penyatuan. Kuala Lumpur: Institut Terjemahan Buku Negara dan Institut Kajian Etnik.

[10] Siti Rahimah Mustaffa, Raja Masittah, R.A. \& Normahdiah, S.S. 2014. Kekeliruan jati diri punca bahasa bercampur aduk. Jurnal Bahasa. 14: 134-158.

[11] Sitti Hasnah Bandu, Abdul Razaq Bin Ahmad \& Mohd Mahzan Bin Awang. 2015. Patriotism: Issues and challenges in Malaysia. International conference on current issues in education 2015. Ogos.

[12]Zairil Khir Johari. 2015. Masalah dengan sekolah vernakular.

https://www.roketkini.com/2015/09/08/masalah-dengansekolah-vernakular/ [30 Ogos 2019]. 